\title{
Biology and assessment of the thread fin bream Nemipterus japonicus in Gulf of Suez, Egypt
}

\author{
Amal M. Amine \\ National Institute of Oceanography and Fisheries, Red Sea and Suez \& Aqaba Gulfs Branch \\ P. O. Box 182, Suez, Egypt \\ aminamal30@yahoo.com
}

\section{ABSTRACT}

Monthly data of length frequency for Nemiptrus japonicus landed between September 2010 to July 2011 from commercial catch at El-Attaka fish landing along the Gulf of Suez were used to estimate the age composition, growth parameters, sex ratio ,condition factor, length at first sexual maturity, mortality exploitation rate, relative yield per recruit, and relative biomass per recruit. The maximum total length and weight were $29 \mathrm{~cm}$ and $219.92 \mathrm{~g}$, respectively. Females and males were represented by $46 \%$ and $54 \%$, respectively, of the particular population of the species. The total length of females ranged from $8.5-25 \mathrm{~cm}$, and of males $10-29 \mathrm{~cm}$. The lengthweight relationship for combined sexes were estimated as $\mathrm{W}=0.025^{*} \mathrm{~L}^{2.733}$. Age determination based on length frequency data showed that the life span extended to five years. The von Bertaianffy growth parameters were estimated as: $L \infty=33.65 \mathrm{~cm}$, $\mathrm{K}=0.450$ and $\mathrm{t}_{\mathrm{o}}=-0.123$. Females matured at a total length of $12.5 \mathrm{~cm}$, while males matured at a total length of $11.4 \mathrm{~cm}$.

The mortality rates were computed as $(\mathrm{Z})=1.75 \mathrm{y}^{-1},(\mathrm{M})=0.529 \mathrm{y}^{-1}$ and $(\mathrm{F})$ $=1.221 \mathrm{y}^{-1}$. The exploitation rate was estimated as $\mathrm{E}_{\text {cur. }} 0.697$. The relative yield per recruit and relative biomass per recruit analysis showed that the stock of Nemiptrus japonicus in the Gulf of Suez was overexploited.

Keywords: Nemiptrus japonicus, age, growth parameters, sex ratio, length at first sexual maturity, mortality rates, exploitation rate, relative yield per recruit, relative biomass per recruit.

\section{INTRODUCTION}

The thread fin bream Nemipterus japonicus is a demersal species belonging to family Nemipteridae which have an economic importance in the trawl fishery in the Gulf of Suez. It is very abundant in coastal water, found on mudy or sandy bottoms in 5 to $80 \mathrm{~m}$ depth, usually found in schools (Kerdgari et al., 2009). It has a wide distribution from the Red Sea and eastern shores of Africa to the Philippines and Japan. It is one of the major species in the southern Red Sea (Ben-Yami, 1964) and in the Gulf of Suez (Ben-Tuvia and Grofit, 1973). The present of this fish in the Mediterranean is evidently due to migration from the Red Sea via the Suez Canal (Golani and Sonin, 2006). Six nemipterid species belonging to two genera were recorded in the Gulf of Suez (Breikaa, 1996). The stock assessment of $N$. japonicus in the Gulf of Suez was studied by Breikaa (1992 and1996) and EL-Ganainy et al. (2003). Also, its population dynamics in the Indo Pacific region was studied by Krishnarnoorthi (1976); Ingles and Pauly (1984); Edward, Bakhader and Shaher (1985); Vivekanandan and James (1986); Murty (1987); Devaraj and Gulati (1988); Khan and Mustafa (1989); Iqbal (1991); Mostafa (1994); Lavapie ,Gonzales and Gayanilo (1997); Al-Sakaff and Esseen (1999); Rajkumar et al. (2003) and Joshi (2010). Furthermore, the biology and fishery of $N$. japonicus in the Indian Ocean region, South China Sea, Arabian Sea and Red Sea were described by Kuthalingam 
(1969); Krishnamoorthi (1971, 1973,1974); Eggleston (1972); Vinci and Nair (1974); Fursa (1979);Vine (1982); Murty (1984); Nair and Jayaprakash (1986); Vivekanandan and James (1986); Bakhsh (1996); Rajkumar et al. (2003); Manojkumar (2004); Kerdgari et al. (2009).

The present work aims to study the spawning season and seasonal change in GSI and provides information on growth parameters and mortality rates which used in management for Nemipterus japonicus in the Gulf of Suez.

\section{MATERIALS AND METHODS}

Monthly samples of Nemipterus japonicus were collected during the period from September 2010 to July 2011. A total of 569 individuals (274 males, 231 females and 46 immature) were caught by bottom trawlers at Attaka harbor. Length measurements of specimens were taken to the nearest centimeter and weighed to the nearest gram. Sex was determined and maturity stages of Nemipterus japonicus were identified based on the scale of Nikolsky (1963) (I immature, II resting stage, III mature, IV nearly ripe, V ripe, and VI spent). Gonads were weighed to the nearest milligram.

The gonado-somatic index of each sex was calculated using the following formula of De Viaming et al. (1982); GSI=GW*100/ BW

Where: $\mathrm{GW}=$ gonad weight and $\mathrm{BW}=$ body weight.

The relationship between body weight (W) and total length (L) was estimated by Ricker (1973): $\mathrm{W}=\mathrm{aL}^{\mathrm{b}}$

The Condition Factor $(\mathrm{K})$ was calculated after Pauly (1983) where $\mathrm{K}=\mathrm{W} * 100 / \mathrm{L}^{3}$ (W= gutted body weight in $\mathrm{gm}, \mathrm{L}=$ total length in $\mathrm{cm}$ ).

The FISAT software (Gayalino et al., 1995) was used with the monthly length-frequency distributions for determination of age and growth rates by applied Bhattacharya (1967) method and the analysis of the population parameter estimates were done.

The estimates of the von Bertalanffy growth parameters, the asymptotic length $(L \infty)$ and the growth coefficient $(\mathrm{K})$, were obtained using the ELEFAN I routine of FISAT which allows the estimation of growth parameters without knowing the age of the individuals (Pauly and David, 1981).

The theoretical age at length zero $\left(\mathrm{t}_{\mathrm{o}}\right)$ was estimated using Pauly's empirical equation (1979): $\log \left(-\mathrm{t}_{\mathrm{o}}\right)=-0.3922-0.2752 \log \mathrm{L}_{\infty}-1.038 \log \mathrm{K}$

The growth performance index, $\Phi^{\prime}$ of the species was estimated after Pauly and Munro (1984): $\Phi^{\prime}=\log 10 \mathrm{~K}+2 \log 10 \operatorname{L} \infty$

The longevity $\left(\mathrm{t}_{\max }\right)$ was obtained after Pauly (1983) by the following equation:

$$
\mathrm{t}_{\max }=\mathrm{t}_{0}+3 / \mathrm{k}
$$

Where $t_{\max }$ is the approximate maximum age of a fish in a given population.

The total mortality $(\mathrm{Z})$ was estimated from the length converted catch curve method described by Pauly (1983). Natural mortality was computed by applying Rikhter and Efanoves (1976) equation: $\mathrm{M}=\left(1.52 /\left(\mathrm{t}(\mathrm{mass})^{\wedge} 0.72\right)-0.16\right.$.

The fishing mortality coefficient $(\mathrm{F})$ was calculated directly: where $\mathrm{F}=\mathrm{Z}-\mathrm{M}$.

The current exploitation rate $\left(E_{\mathrm{cur}}\right)$ was estimated by the formula of Gulland (1971): $\mathrm{E}=\mathrm{F} / \mathrm{Z}$.

The length at first capture $\mathrm{L}_{C}$ was estimated by Pauly(1984a,b). The Relative yield and biomass-per recruit analysis were used to assess the fishery. Growth parameters $\left(\mathrm{K}\right.$ and $\left.\mathrm{L}_{\infty}\right)$, mortality $(\mathrm{M})$, and length at first capture $\left(\mathrm{L}_{\mathrm{C}}\right)$ were used as model inputs, and the knife-edge selection was assumed. The Beverton and Holt 
(1966) yield per recruit model modified by Pauly and Soriano (1986) was used to estimate the size at maximum yield per recruit and to predict the effects of increasing the mean size at first capture $\left(\mathrm{L}_{\mathrm{C}}\right)$ at which yield per recruit would be maximized.

\section{RESULTES}

\section{Length- weight relationship}

The total length of females Nemipterus japonicus ranged from $8.5-25 \mathrm{~cm}$, and that of males from $10-29 \mathrm{~cm}$. The corresponding total weight ranged from $12.42-159.28 \mathrm{gm}$, and $17.34-219.92 \mathrm{gm}$. The length-weight relationship was computed and the obtained equation was in the form of $\mathrm{W}=0.025 * \mathrm{~L}^{2.733}\left(\mathrm{R}^{2}=0.94\right)$

This relationship is shown in Fig. (1).

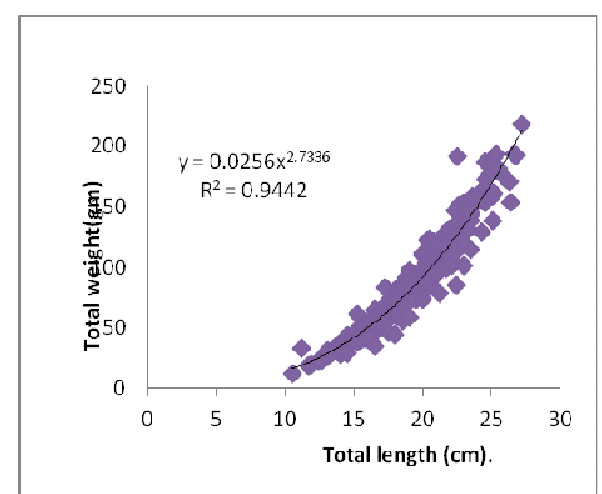

Fig. 1: Length -weight relationship of $N$. japonicus in the Gulf of Suez.

\section{The condition factor $(k)$}

The mean values of condition factor ranged between $0.9577-1.728$ and 1.007-1.622 for males and females, respectively (Fig. 2).

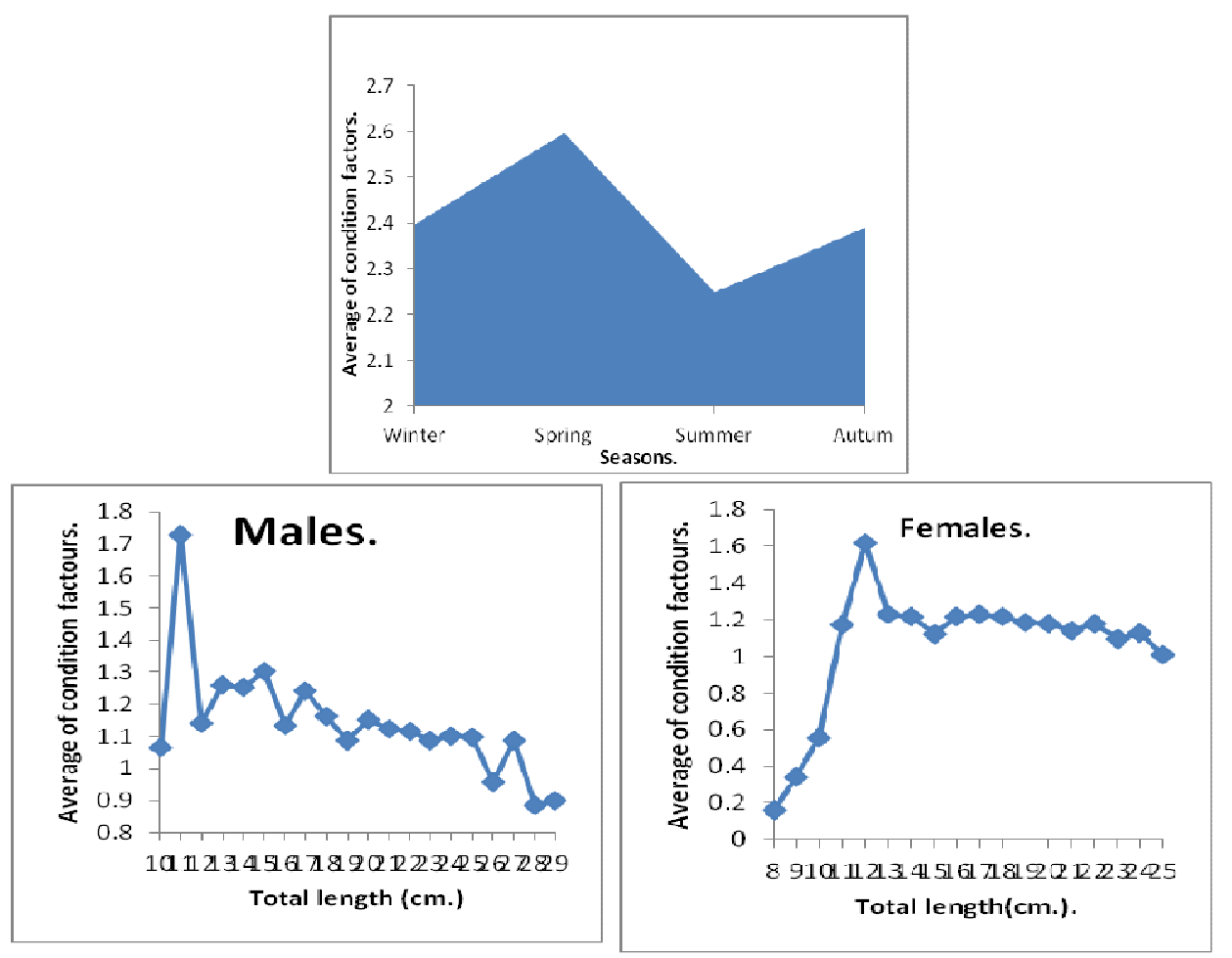

Fig. 2: Average of condition factors for males and females of N. japonicus in the Gulf of Suez. 
The maximum values $(11 \mathrm{~cm}$ for males and $12 \mathrm{~cm}$ for females) were recorded in spring. There was a decline in values of $\mathrm{K}$ at summer, followed by an increase in autumn and winter for combined sexes.

\section{Sex ratio}

From Fig. (3), it was obvious that the over all sex ratio (M/F) was1:1.19. Males were dominant in January (87\%), while females were dominant in February (69\%), while they had the same percent age (50\%) in July.

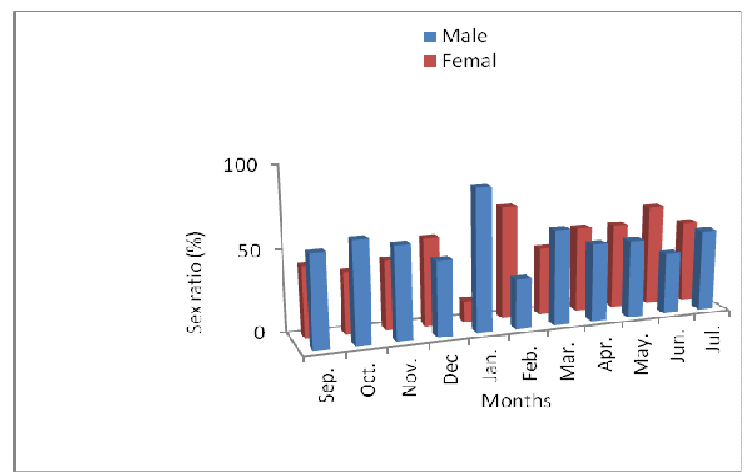

Fig. 3: Monthly variation in sex ratio of $N$. japonicus in the Gulf of Suez.

\section{Gonad Somatic Index (GSI)}

Monthly average variation in GSI of both sexes of Nemipterus japonicus was quite apparent in Fig. (4). Females had the maximum values in September (2.3) and May (2.6) then gradually decreased to reach a minimum value in February (0.87). The maximum values of GSI for males were recorded in September (0.42) and May (0.49) and reached minimum value in February (0.25). Also, another peak was found in May for both sexes followed by a lower record of GSI in July (Fig.4).
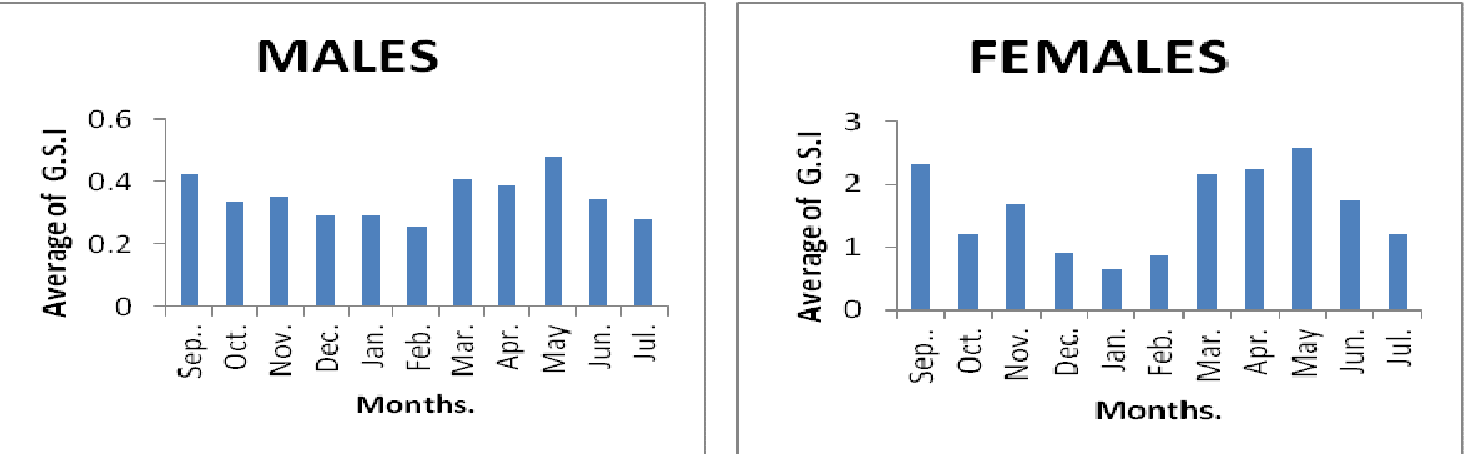

Fig. 4: Seasonal variation of the average Gonadosomatic index of N. japonicus in the Gulf of Suez.

\section{Length at first maturity}

The length of the smallest mature female was $10 \mathrm{~cm}$. About $50 \%$ of females and males were mature at lengths of $11.4 \mathrm{~cm}$ and $12.5 \mathrm{~cm}$, respectively (Fig. 5).
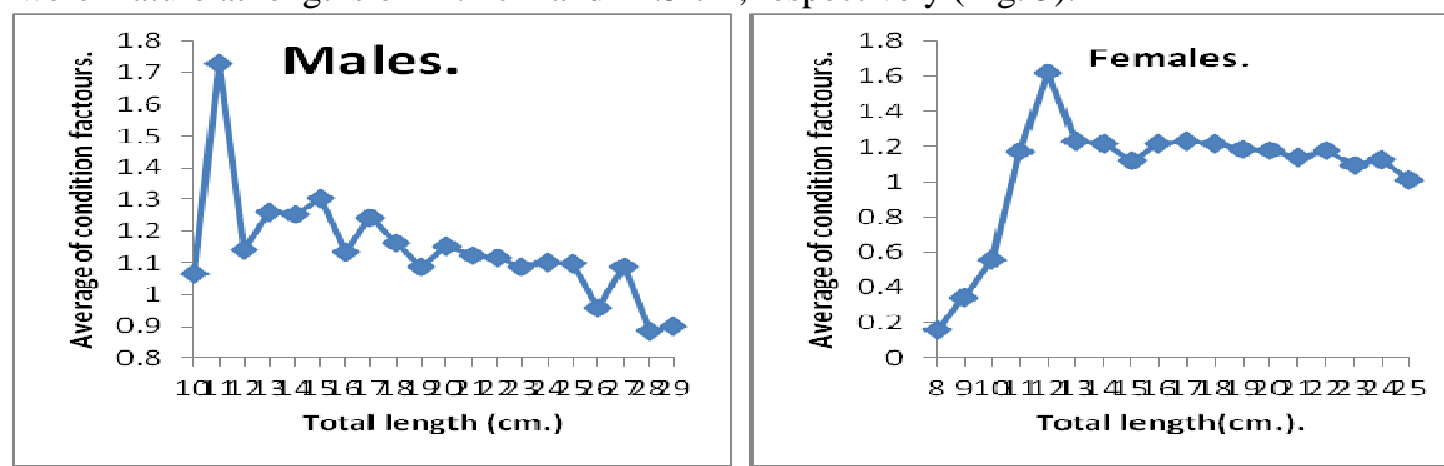

Fig. 5: Length at first sexual maturity of males and females N. japonicus in the Gulf of Suez. 


\section{Age and growth}

Age was determined based on length frequency analysis using Bhattacharya's method represented in Fig. (6) and Table (1). The life span was about 5 years with a predominant of age group two in the catch $(42.5 \%)$ with mean lengths of $12.65 \mathrm{~cm}$, $16.46 \mathrm{~cm}, 19.90 \mathrm{~cm}, 23.72 \mathrm{~cm}$ and $26.99 \mathrm{~cm}$, respectively, while zero group was calculated at $9.50 \mathrm{~cm}$.

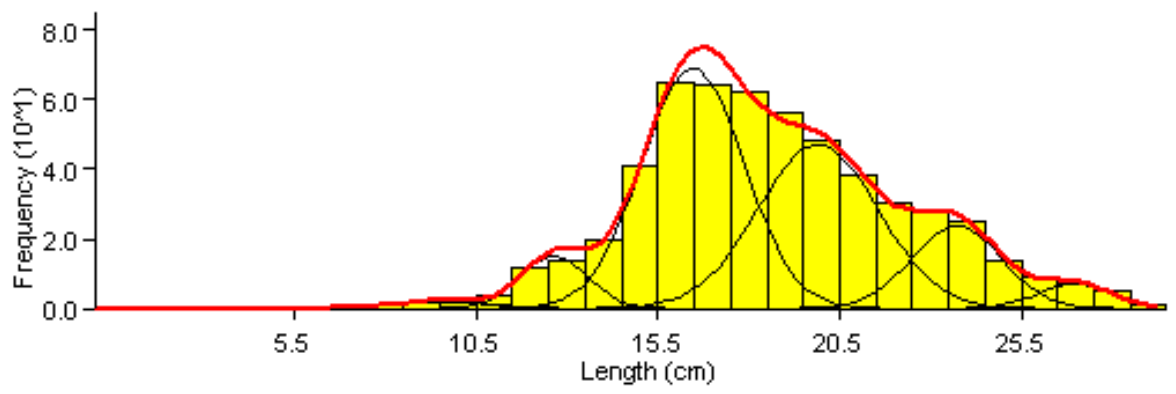

Fig. 6: Age determination by the Bhattacharya method.

Table 1: Summary of the calculated spawning time of Nemipterus japonicus in different regions.

\begin{tabular}{|l|l|l|}
\hline Locality & Date of spawning & Source \\
\hline South China & May-October & Krishnamoorthi (1971) \\
\hline Eastern part of Arabian Sea & Year round (peak October) & Eggleston(1972) \\
\hline Off Waltair & September-November & Weber \& Jothy (1977) \\
\hline East Malaysian & November-February & Fursa (1979) \\
\hline At Waltair & December-February and June-July & Dan (1980) \\
\hline In WS Hoar & In Summer & Nagahana (1983 ) \\
\hline Kakinada & August-April(Peak February-December & Murty (1984) \\
\hline Madras & June-March(Peak December-March) & Vivekanandan \& James (1986) \\
\hline Jizan area & Year round (peak November-May) & Bakhsh(1996) \\
\hline Off Cochin & July-August & Joshi (2010) \\
\hline Gulf of Suez & September-May & Present study \\
\hline
\end{tabular}

\section{Theoretical growth in length}

The von Bertalanffy growth equation for growth in length for Nemipterus japonicus were estimated as follow:

\section{Theoretical growth in weight}

$$
\mathrm{Lt}=33.65\left(1-\mathrm{e}^{-. .450(\mathrm{t}+0.132)}\right)
$$

The von Bertalanffy growth in weight for Nemipterus japonicus were predicated as follows:

$$
\mathrm{Wt}=372.55\left(1-\mathrm{e}^{0.450(\mathrm{t}+0.123)}\right)^{2.733}
$$

\section{The longevity}

The longevity $\left(\mathrm{t}_{\max }\right)$ was calculated as 6.5 years.

\section{Growth performance index}

Growth performance index $(\varnothing)$ is the best index for expressing the fish growth and it was estimated as 2.71for of N. japonicus in the Gulf of Suez.

\section{Mortality}

Total mortality rate $\left(\mathrm{Z}=1.750\right.$ year $\left.^{-1}\right)$ was represented in Fig. (7). The natural mortality was estimated as $(M)=0.529$ year $^{-1}$ and the fishing mortality was $(\mathrm{F})=1.221$ year $^{-1}$. 
Length-Converted Catch Curve

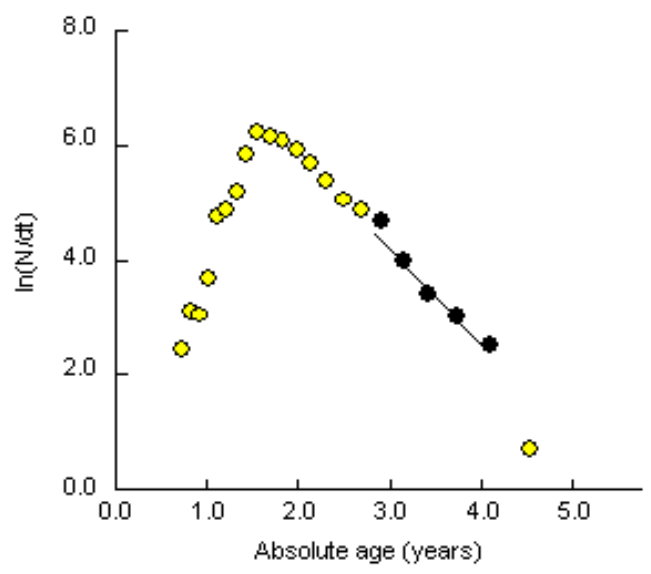

Fig. 7: Length converted catch curve of $N$. japonicus in the Gulf of Suez.

\section{Exploitation rate}

The exploitation rate (Ecur) was found to be 0.697.

\section{Length at first capture:}

In the present study length at first capture was $11.48 \mathrm{~cm}$

\section{Relative yield per recruit, relative biomass per-recruit:}

Nemipterus japonicus is the most dominant species in the nemipterid catch from the Gulf of Suez. The relative yield per recruit and the biomass per recruit (B/R) as a function of exploitation rate (E) are shown in Fig. (8). It is indicated that the maximum yield per recruit was obtained at $\left(\mathrm{E}_{\max }=0.543\right)$. The economic exploitation rate $E_{0.1}$ equals 464 and at which the marginal increase in $Y / R$ reaches $1 / 10$ of the marginal increase computed at very low value of $E$. $E_{50}=0.323$ where $E_{50}$ is the exploitation level which will result in a reduction of unexploited biomass by $50 \%$.

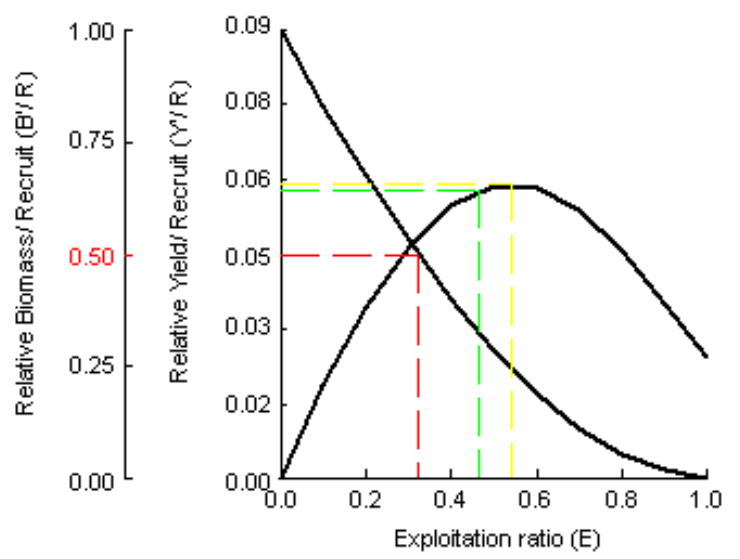

Fig. 8: Current yield per recruit analysis of N. japonicus in the Gulf of Suez. at ( $\mathrm{LC}=11.48$ )

\section{DISCUTION}

The value of the condition factor $(\mathrm{K})$ have been used to measure various ecological and biological factors such as degree of fatness, gonadal development and the suitability of the environment with regard to the feeding condition (Mac Gregoer, 1959). In the present study the maximum values of $K$ were recorded at $11 \mathrm{~cm}$ for males and $12 \mathrm{~cm}$ for females, and were obtained at spring followed by decline at 
summer and increased again in autumn and winter for combined sexes. This may be attributed to sexual maturation.

The highest values of the monthly GSI for both sexes of $N$. japonicus in the Gulf of Suez were in September and May, while the minimum values were reported in February and July which may indicate that N. japonicus in the Gulf of Suez had prolonged spawning season extending from September to February and from May to July.

The estimated spawning time of Nemipterus japonicus in different regions of the world is given in Table (2). Nagahana (1983) demonstrated that peaks of spawning occur in Summer which was similar to the present observation. However, Eggleston (1972), Weber and Jothy (1977), Dan (1980) and Murty (1984) found that spawning season varies from region to another according the environmental factors.

Table 2: Mean assigned lengths, standard deviation for $N$. japonicus from the Gulf of Suez estimated by Battacharya method.

\begin{tabular}{|l|l|l|l|l|}
\hline Age group & Mean & S.D & Population & S.I. \\
\hline Zero & 9.50 & 1.200 & 7 & n.a. \\
\hline 1 & 12.65 & 0.910 & 34 & 2.190 \\
\hline 11 & 16.46 & 1.400 & 242 & 2.220 \\
\hline 111 & 19.90 & 1.650 & 195 & 2.040 \\
\hline $1 \mathrm{~V}$ & 23.72 & 1.230 & 73 & 2.090 \\
\hline $\mathrm{V}$ & 26.99 & 1.020 & 18 & 2.080 \\
\hline
\end{tabular}

The length and age at first sexual maturity are very important parameter in fisheries research to assess the optimum age of first capture of a species and to determine minimum legal size that may be needed to maintain the suitable spawning stock and to ensure at least one spawning for the mature individuals. Length at first sexual maturity of Nemipterus japonicus was $11.4 \mathrm{~cm}$ for male and $12.5 \mathrm{~cm}$ for females. The obtained result was similar with that of Murty (1987), Bakhsh (1996) and Rajkumar et al. (2003) who reported Lc at $12.5 \mathrm{~cm}, 11 \mathrm{~cm}$ and $128 \mathrm{~mm}$, respectively. On the other hand, Manojkumar (2004) determined sexual maturity of females Nemipterus japonicus at length $14.0 \mathrm{~cm}$ and $50 \%$ maturity at $18.3 \mathrm{~cm}$ and Krishnamoorthi (1971) found the above limit at $16.5 \mathrm{~cm}$. The differences in values of Lc and age at first sexual maturity can be attributed to variations in food and water temperature and stock density which may influence the growth of fish and length at maturity (Tormosova, 1983 ).

Based on the present results, length at first capture was 11.48 and lengths at first maturity were $11.4 \mathrm{~cm}$ for males and 12.5 for females for Nemipterus japonicus from the Gulf of Suez. This indicats that these individual do not have the chance to reproduce before they are removed from the population. Similar results were obtained by Berikaa (1996) and El-Ganainy (2003) who estimated the length at first capture for Nemipterus japonicus from the Gulf of Suez as $12.66 \mathrm{~cm}$ and $11.68 \mathrm{~cm}$ for males and females, respectively.

The values of growth parameters of Nemipterus japonicus in the present study from the Gulf of Suez compared with those recorded for the same species from other Indo-Pacific regions are shown in Table (3). It is hoticed the presence of agreement with most of the previous studies, except those of Khan and Mustafa (1989); Mustafa (1994); Mustafa (1998). The differences may be due to variation in population structure and environmental condition.

The longevity $\left(\mathrm{t}_{\max }\right)$ of Nemipterus japonicus was estimated to be about 6.5 years in the Gulf of Suez, however the maximum number of fishes caught was 
recorded at age group two which indicated that they caught before they grow large enough to add significantly to the stock biomass, and this cause growth overfishing.

Table 3: Summary of the estimated growth parameters of Nemipterus japonicus in different Indo- Pacific reigons.

\begin{tabular}{|l|l|l|l|l|l|}
\hline Locality & $\mathrm{L} \infty(\mathrm{cm})$ & $\mathrm{K} \mathrm{year}^{-1}$ & $\mathrm{t}_{\mathrm{o}}$ & $\varnothing$ & Source \\
\hline Philippine & 30.00 & 0.700 & & 2.800 & Ingles and Pauly (1984) \\
\hline Gulf of Aden & 29.10 & 0.310 & 0.048 & 2.420 & Edward et al (1985) \\
\hline India & 30.50 & 1.004 & 0.226 & 2.970 & Vivekanandan and James (1986) \\
\hline India & 33.90 & 0.520 & -0.160 & 2.776 & Murty (1987) \\
\hline India & 29.80 & 0.821 & & 2.860 & Devaraj and Gulati (1988) \\
\hline Bangladesh & 24.16 & 1.060 & & 2.791 & Khan and Mustafa (1989) \\
\hline Pakistan & 28.80 & 0.460 & & 2.580 & Iqbal (1991) \\
\hline Gulf of Suez & 28.64 & 0.495 & -0.122 & 2.609 & Breikaa (1992) \\
\hline Bangladesh & 24.50 & 0.940 & & 2.750 & Mustafa (1994); \\
\hline Gulf of Suez & 29.27 & 0.462 & -0.198 & 2.597 & Breikaa (1996) \\
\hline Philippine & 28.30 & & & & Lavapie et al (1997) \\
\hline Bay of Bengal & 25.60 & 0.940 & & 2.790 & Mustafa (1999) \\
\hline Gulf of Suez & 28.35 & 0.63 & -0.435 & 2.794 & El-Ganainy and Mehanna. (2003) \\
\hline Gulf of Suez & 33.65 & 0.450. & -0.123 & 2.71 & Present study \\
\hline
\end{tabular}

The current exploitation rate Ecur $=0.697$ was higher than that required to give the maximum yield per recruit $($ Emax $=0.543)$ and also higher than the optimum exploitation rate $\left(\mathrm{E}_{50}=0.323\right)$ which maintain $50 \%$ of the stock biomass. This indicated that Nemipterus japonicus in the Gulf of Suez are exposed to overexploitation, so that $\mathrm{E}_{\mathrm{cur}}$ must be reduced by about $28 \%$. These results confirm the results of El-Ganainy (2003) who reported that there was over-exploitation by the trawl fishing in the Gulf of Suez and $E=0.696$.

Briekaa (1996) estimated the maximum sustainable yield and found that the fishing pressure extracted in the Gulf of Suez for nemipterid catch must be reduced by about $44 \%$.

The present and previous studies recommended that to mange Nemipterus japonicus in the Gulf of Suez, the adults must be protected during the major spawning season. A seasonal closer from May to September can be provide better breeding opportunities for adults and will provide a good fishery management measure for this species. Also, the length at first capture of Nemipterus japonicus must be increased to maintain the stock and to give the chance to mature animals to breed at least once through its live-span. Moreover, the trawl fishery operating the Gulf of Suez must be managed by reducing effort (number of boat, and number of landings). Finally, the nursing ground of this economically important species must be protected from pollution to reduce the rate of natural mortality of this species in the Gulf of Suez.

\section{REFERENCE}

Al-Sakaff, H.; Esseen, M. (1999). Length-weight relationship of fishes from Yemen water (Gulf of Aden and Red Sea). Naga, ICLARM Q, 22 (1):41- 42.

Bhattacharya, C.G. (1967). A simple method of resolution of a distribution into Gaussian components Biometrics, 23:115-135.

Bakhsh, A.A. (1996). The Biology of Thread Bream, Nemipterus japonicus (Bloch) from the Jizan rejoin of the Red Sea. J. Kau. mar. Sci., vol.7, special issue Symp. on Red Sea mar. Environ .Jeddah. pp.179-189. 
Ben-Yami, M. (1964). Report on the fisheries in Ethiopia. Department for International Cooperation, Ministry for Foreign Affairs, State of Israel, Jerusalem.

Ben-Tuvia, A. and Grofit, E. (1973). Exploitation trawling in the Gulf of Suez, November, 1972. Fisheries Fish Breed. Israel, 8:8-16.

Bertalanffy, L. von 1938. A quantitative theory of organic growth (Inquiries on growth Laws. 2). Hum. Biol., 10: 181-213.

Beverton, R.J.H. and Holt, S.J. 1966. Manual of methods for fish stock assessment. Part 2. Tables of yield functions. FAO Fish. Tech. Pap./FAO Doc. 38 Rev. 1: $67 \mathrm{pp}$.

Breikaa, M.I.M. (1992). Astudy of population dynamics of the threadfin bream Nemipterus japonicus in the Gulf of Suez.M.SC. Thesis, Faculty of Science, Cairo Univerisity, 260pp.

(1996). Dynamics and fisheries management of the threadfin bream Nemipterus japonicus (Pisces: Nemipteridae) in the Gulf of Suez. Ph. D. Thesis, Faculty of Science, Cairo Univerisity, 318pp.

Dan, S. S. (1980). Intra-ovarian studies and fecundity in Nemipterus japonicus (Bloch). Indian J. Fish., 24: 48-55

De Viaming, VG.; Grossman, F. Chapman (1982). On the use of gonadosomatic index. Comp. Biochem. Physiol., 73: 31-39.

Devaraj, M. and Gulati, D. (1988). Assessment of the stock of threadfin bream Nemipterus japonicus in the north -west continental shelf of India. In M. Mohan Joseph (ed). The first Indian Fisheries Forum Proceeding. Asian Fisheries Society, Indian Branch,Mangalore. pp.159-164.

Edward, R.R.C.; Bakhader, A. and Shaher, S. (1985). Growth, mortality, age composition and fishery yield of fish from the Gulf of Aden. J. Fish. Biol., 27:13-21.

Eggleston, D. (1972). Patterns of biology in Nemipteridae. J. Mar. Biol. Ass. Indian 14:357-364.

EL-Ganainy, A. and Mehanna, S. F. (2003). Resource assessment and management prospective of two Nemipterid species (nemipterus japonicus and N.zysron) in the Gulf of Suez. Bull., Nat. Inst of Oceanogr. and fish., A.R.E., 29:15-29.

Fursa, T. I. (1979). On the seasonal nature of the spawning of fishes in the Eastern part of the Arabian Sea. J. Ichthyio, 19:66-74.

Ingles, J. I. D. and Pauly, (1984). An Atlas of the Growth, mortality and recruitment of Philippines fishes. ICLARM Tech. Rep., pp.13-127.

Iqbal, M. (1991). Population dynamics of Nemipterus japonicus from the Northern Arabian Sea, Pakistan. Fishbyte, 9(1):16-22.

Joshi, K. K. (2010): Population dynamics of Nemipterus japonicus (Bloch).in the trawling ground off Cochin. Indian J. Fish., 57(1):7-12

Kerdgari, T.; Valinassab, S.; Jamili, M.; Fatemi, R. and Kaymaram, F. (2009). Reproductive biology of the Japanese Threadfin Bream, Nemipterus japonicus, in the Northern of Perisan Gulf. Jornal of Fisheries and Aquatic Sci., 4 (3):143149.

Khan, M. D. G. and Mustafa, M. D. G. (1989). Length-Frequency based population analysis of the threadfin bream Nemipterus japonicus of the Bangladesh coast. Indian J. fish., 36(2): 163-166.

Krishnamoorthi, B. (1971). Biology of the threadfin bream, Nemipterus japonicus (Bloch). Indian J. Fish., 18:1-21. 
(1973). An assessment of Nemipterus fishery off Andhraorissa coast based exploratory fishing. Proc. Symp. Living Resources of the sea around India.CMFR Institute Cochin.pp.495-516.

(1974). A note on the size different between males and females of Nemipterus japonicus (Bloch). Indian J. Fish., 21: 608-610.

(1976). A note on mortality rate and yield per recruit in Nemipterus japonicus (Bloch). Indian J. Fish., 32: 252-256

Lavapie-Gonzales, F.S.R.; Gonaden, F.C. and Gayanilo, Jr. (1997). Some population parameters of commercially important fishes in philippines.Bureau of Fisheries and Aquatic resources, Philippines.114pp.

Mac Gregoer JS. (1959). Relation between fish condition and population size in the sardine (sardinops cacrulea) US. Fish. Wild. Fish. Bull, 166: 60.

Manojkumar, M. P. P.(2004). Some aspect on the biology of Nemipterus japonicus (Bloch) from Veraval in Gujarat. Indian J .Fish., 51:185-191.

Mustafa, M.G. (1994). Length-based estimates of vital statistics in threadfin bream Nemipterus japonicus from Bay of Bengal, Bangladesh. Naga, ICLARM Q., 17(1):34-37.

Mustafa, M.G. (1999). Population dynamics of penaeid shrimps and demersal finfishes from trawl fishery in the Bay of Bengal and implications for their management. Ph.D. Thesis, Department of Zoology, University of Dhaka, Dhaka, Bangladesh.

Murty, V. S. (1984). Observation on the fisheries of Thread Fin Bream (Nemipteridae) and on the biology of Nemipterus japonicus (Bloch) from Kakinada. Indian J. Fish., 31:1-18.

Murty, V. S. (1987). Further studies on the growth and yield per recruit of Nemipterus japonicus (Bloch) from the trawling ground off Kakinada. Indian J. Fish., 34(3): 265-276.

Nagahama Y. (1983). The Finctional morphology of teleost gonads .In WS Hoar, DJ Randall, EM Donaldson, eds. Fish physiology. Vol. 9, Reproduction. New York: Academic press, pp.223-275.

Nair, K. V. S. and Jayaprakash, A. A. (1986). A note on the monsoon fishery of threadfin breams off Cochin. Indian. J. Fish., 33: 106-112

Nikolsky. G. (1963). The Ecology of Fishes (Transelated from Russian), Academic Press, London, UK,

Vinci, G. K. (1983). Threadfin breams (Nemipterus) resources along the Kerala coast with notes on biology of Nemipterus japonicus. Indian J. Fish., 29:37- 49

Vinci, G. K. and Nair, A. K. K. (1974). Length-weight relationship in the threadfin bream Nemipterus japonicus, along the Kerala coast. Indian. J. Fish., 21: 299-302.

Vivekanandan, E. and James, D. B. (1986). Population dynamics of Nemipterus japonicus (Bloch) in the trawling ground of Madras. Indian J. Fish., 33(2): 145-154.

Rajkumar, U.; Narayana-Rao, K. and Jose-Kingsly, H. (2003). Fishery, biology and population dynamics of Nemipterus japonicus (Bloch) off Visakahapatnam, Indian J. Fish., 50:319-324.

Rickter, W. E. (1973). Linear regressions in fisheries research. J. Fish. Res. Board Can., 30(3): 409-434.

Rikhter, V. A. and Efanov, V. N. (1976). On one of the approaches to estimation of natural mortality of fish populations ICNAF Res. Doc. 79/VI/8. 12pp. 
Tormosova ID. (1983). Variation in The age at maturity of the North Sea haddock. Melanogrammus aeglefinus (Gadidae). J. Ichthyology., 23:68-74.

Gayanilo, Jr F.C.; Sparre, P. and Pauly, D. (1995). FAO-ICLARM stock assessment tools (FiSAT) user's manual. FAO Computerized Information Series (Fisheries), $8: 126$.

Golani, D. and Sonin, O. (2006). The Japanese threadfin bream Nemipterus japonicus a new Indo-Pacific fish in the Mediterranean Sea .J. Fish Biol., 68: 940-943.

Gulland, J. A. (1971). The Fish Resources of the Ocean. West Byfleet, Surrey. Fishing News Books Ltd. FAO Rome, 255 pp.

Pauly, D. (1979). Theory and management of tropical multispecies stocks: a review with emphasis on the Southeast Asian demersal fisheries. ICLARM Study Review, 35 pp.

Pauly, D. (1983). Some simple methods for the assessment of tropical fish stocks. FAO Fisheries Tech. Pap., FAO. Rome, 234: 52.

Pauly, D. (1984a). Length-converted catch curves. A powerful tool for fisheries research in the tropics. (part II). ICLARM Fishbyte, 2(1): 17-19.

Pauly, D. (1984b). Length-converted catch curves. A powerful tool for fisheries research in the tropics. (III: conclusion). ICLARM Fishbyte, 2(3): 9-10.

Pauly, D. and David, N. (1981). ELEFAN I: a basic programme for the objective extraction of growth parameters from length-frequencies data. Meerestorschiung, 28: $205-211$

Pauly, D. and Munro, J.I. (1984). Once More on the .Comparison of Growth in Fish. and Invertebrates. Fish Byte, 2: 21-23.

Pauly, D. and Soriaano, M. L. (1986). Some practical extensions to Beverton and Holt's relative yield-per-recruit model. In: J.L. Maclean, L.B. Dixin and L.V. Hosillo (Eds.), The first Asian Fisheries Forum. Asian Fisheries Society, Manila, Philippines, pp.491-496

Weber. W. and Jothy, A. A. (1977). Observation on the fish Nemipterus spp. (Family:Nemipteridae) in the coastal waters of East Malaysia. Arch. Fisch Wiss., 28:109-122

\section{ARABIC SUMMARY}

\section{بيولوجية وتنظيم اسماك الصرع (Nemiptrus japonicus ) في خليج السويس ـ مصر}

$$
\begin{aligned}
& \text { أمل محمد محمود امين } \\
& \text { المعهز القومي لعلوم البحار و المصايد فرع مين السويس, مصر }
\end{aligned}
$$

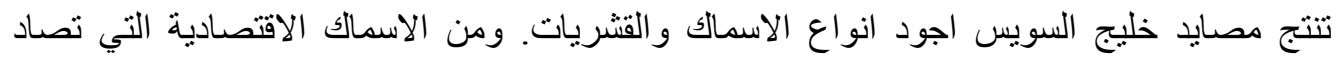

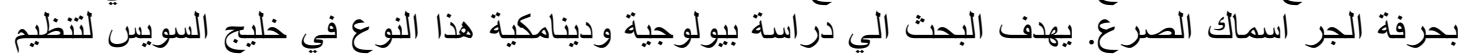

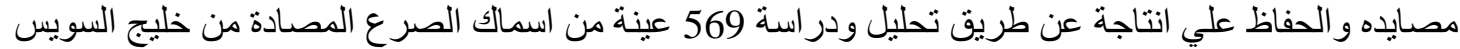

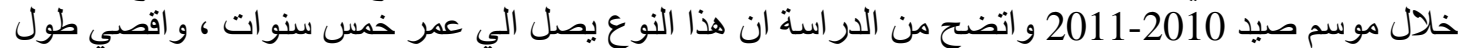

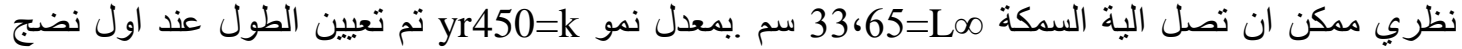

$$
\begin{aligned}
& \text { جنسي وكان للاناث عند 12,5 سم اما الذكور عند 11,4 سم بينما الطول عند اول مصنيد 11,48 سم. 11,4 كما شملت }
\end{aligned}
$$

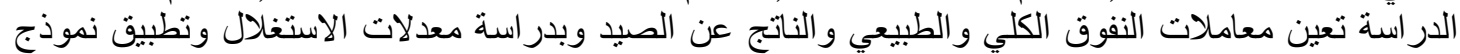

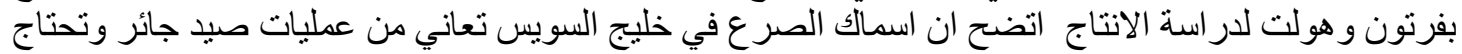

$$
\begin{aligned}
& \text { مصايده الي تنظيم وتخفيض جهد الصيد حتي نصل الى الى الانتاج الامنل و المستمر. }
\end{aligned}
$$

